\title{
Spiritual counseling on anxiety level in (Lombok) Indonesian earthquake victims
}

\author{
Zurriyatun Thoyibah¹, Dewi Nur Sukma Purqoti², Elisa Oktaviana ${ }^{3}$ \\ 1,2,3 STIKES YARSI Mataram, Indonesia. Email: oyiqyarsi@gmail.com
}

\begin{abstract}
Background: An earthquake has an impact on mental health problems. Lombok earthquake victims undergo an anxiety, neurotic, psychotic symptoms, and Post Traumatic Syndrome Disease. Anxiety have an impact on the mind, body and it cause of physical illness. One of the nursing interventions that can be given to deal with anxiety includes spiritual counseling, which is given so that disaster victims accept their conditions, it is not making disaster a burden and reducing anxiety.

Purpose: To determine the effect of Spiritual counseling on anxiety level in (Lombok) Indonesian earthquake victims.

Methods: Quantitative study with a pre-experimental approach using one group pre-post-test design on 25 earthquake victims in Lombok. The instrument was used the Hamilton Anxiety Rating Scale questionnaire and the standard operational procedures for spiritual counseling. Data were analyzed using univariate analysis and $t$ dependent test.

Results: The anxiety score before spiritual counseling was $19.60 \pm 3.26$, while the anxiety score after spiritual counseling was $10.04 \pm 4.13$. Statistical tests showed a significant difference between anxiety levels before and after spiritual counseling for earthquake victims in Lombok $(p<0.05)$.

Conclusion: Earthquake victims in order to improve their spiritual quality by joining religious activities routinely to calm the mind and reduce anxiety or trauma, it is caused by earthquakes.
\end{abstract}

\section{Keywords: Spiritual counseling; Anxiety level; Indonesian; Earthquake victims}

\section{INTRODUCTION}

The earthquake disaster in Lombok on July 29th, 2018 had an impact on all aspects of life both, physical, psychological and social aspects. Earthquake victims, not only undergo the emergency problems such as construction, food, physical conditions due to the earthquake, but also mental health problems (Ramirez, 2005). After a disaster, around $15-20 \%$ undergo the mild or moderate mental disorders that lead to Post Traumatic Syndrome Disease (PTSD), while 3-4\% undergo the severe disorders such as psychosis, severe depression and panic (Sherchan, Samuel, Marahatta, Anwar, Van, Ommeren, \& Ofrin, 2017). Lombok earthquake victims showed that $85.2 \%$ experienced symptoms of neurosis, $29.5 \%$ undergo psychotic symptoms and $64.7 \%$ of victims experienced symptoms of PTSD (Dwidiyanti, Hadi, Wiguna, \& Ningsih, 2018). Where as in earthquake victims, children found $85.1 \%$ experienced mild anxiety and $14.8 \%$ experienced severe anxiety (World Health Organization, 2013; Lieber, 2017).
Earthquakes are related to mental health problems such as depression and post-traumatic stress disorder after a disaster. The condition will get worse if it is not detected early and handled properly, thus requiring mental health services (Dwidiyanti, et al., 2018). Nursing interventions that can be provided to deal with the psychological impact of victims are spiritual counseling.

Counseling is a process that focuses on a person's needed, problems or feelings through two-way active communication, the exchange of experiences, providing solutions based on mutual agreement to find ideas for improving or support coping, problem solving and creating good interpersonal relationships(Bulechek, 2013). Spiritual counseling is counseling that directs the counsel to God with the basic assumption that humans are God's creatures and what will be happening in this world is God's will. Spiritual counseling makes a person able to accept their conditions, not be burdened, and make calamity as a way to increase faith and devotion. The ultimate 
Spiritual counseling on anxiety level in (Lombok) Indonesian earthquake victims

goal of spiritual counseling is so that counselees avoid the problems of neurosis, psychosis, social and spiritual, and individuals have mental health (Lubis, 2007). Previous research explained that there was an effect of nurses' spiritual counseling on the level of anxiety in the families of patients treated in intensive care unit (ICU) at Sleman general hospital (Sugiyanto, 2014). Another study found there was an effect of spiritual support on reducing anxiety levels in preoperative patients in the Surgery ward of Soepraoen Hospital Malang (Wulandari, 2013).

The Excessive anxiety has a detrimental impact on the mind and body and can cause physical illness (Purqoti, 2017). Anxiety is also one of the inhibiting factors in the learning process that can interfere with the performance of cognitive functions so that difficulties in solving problems and it can reduce to everyone's productivity (Williams, Goodwin, \& Cox, 2004). Spiritual counseling is expected to make earthquake victims more resilient and eager to achieve a happy life, willingly accepting the trials caused by the earthquake (Ando, Kuwabara, Araki, Kanehara, Tanaka, Morishima, Kondo, \& Kasai, 2018). The objective of this research was to determine the effect of spiritual counseling on earthquake anxiety levels in Lombok.

\section{RESEARCH METHODS}

This study was quantitative pre-experimental research with one group pre-post test design approach. Before being given the treatment, earthquake victims are first assessed for their anxiety level, then after being treated and their anxiety level reviewed again. The research was carried out in the Gerimak Indah Village and Gunungsari Village, West Lombok Regency in April-June 2019.
The sample in this research was taken using purposive sampling technique. The inclusion criteria of this research were earthquake victims who experienced anxiety, a place to live with West Lombok, Muslims, were cooperative during the research process and willing to participate in research. Exclusion criteria in this research were patients who experienced a decrease in consciousness and withdrew from the research process. The study began with sample selection by giving a HARS questionnaire to measure anxiety levels. Researchers found 40 respondents who experienced mild and moderate anxiety. As for what was set as the research sample, respondents who were experiencing moderate anxiety were 25 respondents. The researcher gives an explanation using the research explanation sheet and asks for approval as a respondent by signing an informed consent.

The instruments of this research isthe Hamilton Anxiety Rating Scale (HARS). In the HARS questionnaire there are 5 different scores as the following: score $<6$ means no anxiety, 6-14 means mild anxiety, 15-27 means moderate anxiety, 28-36 means severe anxiety and $>36$ means panic.

This research was conducted after received approval from the research location. The ethics approval for this study was granted by Research Ethics Commission of West Nusa Tenggara Provincial General Hospital (No: 070.1/14/KEP/2019).

Univariate analysis got mean, standard deviations and percentages for categorical data, normality tests using Kolmogorov-Smirnov and bivariate analyzes using dependent $t$ tests. 
Spiritual counseling on anxiety level in (Lombok) Indonesian earthquake victims

\section{RESEARCH RESULTS}

Table 1. Frequency Distribution Characteristics of Respondents $\mathrm{N}=25$

\begin{tabular}{lccc}
\hline Characteristics of Respondents & $\begin{array}{c}\text { Frequency } \\
(\mathbf{f})\end{array}$ & $\begin{array}{c}\text { Percentage } \\
(\%)\end{array}$ & M \pm SD (Min-Max) \\
\hline Age (year) & & & $62 \pm 16,56(25-79)$ \\
Gender & & & \\
Male & 1 & 4 & \\
Female & 24 & 96 & \\
Education Levels & & & \\
No education & & & \\
Incomplete primary & 11 & 44 & \\
Completed primary & 3 & 12 & \\
Completed secondary & 6 & 24 & \\
Completed high school & 3 & 12 & \\
\hline
\end{tabular}

Table 1 shows that characteristics of respondents, including age, gender, and education levels. The youngest age is 25 years and the oldest age is 79 years. While the average age of respondents is 62 years with a standard deviation of 16.56. Respondents were male as many as 1 person (4.0\%) and female as many as 24 people $(96.0 \%)$, so in this research the majority of the sexes were female. Based on the level of education it can be seen that there were 11 respondents $(44.0 \%)$ who did not go to school, 3 people $(12.0 \%)$ did not complaid in elementary school, 6 people (24.0\%) finished elementary school, 3 people had finished junior high school $(12.0 \%)$ and high school graduates as many as 2 people $(8.0 \%)$, so the majority of respondents in the study were those who did not go to school.

Table 2. Average of Anxiety Score Before and After Spiritual Counseling N = 25

\begin{tabular}{|c|c|c|c|c|}
\hline Variable & Min & Max & Mean \pm SD & $p$-value \\
\hline $\begin{array}{l}\text { Anxiety Score Before } \\
\text { Intervention }\end{array}$ & 16 & 27 & $19,60 \pm 3,26$ & 0,000 \\
\hline $\begin{array}{l}\text { Anxiety Score After } \\
\text { Intervention }\end{array}$ & 2 & 18 & $10,04 \pm 4,13$ & \\
\hline $\begin{array}{l}\text { Anxiety Score Before and } \\
\text { After Intervention }\end{array}$ & & & $9,56 \pm 4,23$ & \\
\hline
\end{tabular}

Table 2 shows that level of anxiety undergo by respondents. Anxiety level undergoes the earthquake victims in Lombok prior to spiritual counseling intervention with the smallest anxiety scale 16 and the greatest anxiety scale 27, with an average anxiety scale of 19.60 and a standard deviation of 3.26 . While anxiety experienced by earthquake victims in Lombok after spiritual counseling intervention with the smallest anxiety scale 2 and the greatest anxiety scale 18, with an average anxiety scale of 10.04 and a standard deviation of 4.1 . The anxiety felt by respondents before and after spiritual counseling had a difference of 9.56 with a standard deviation of 4.23 . The $p$-value $=0,000$ indicates that this value is smaller than the alpha value of $5 \%(0.05)$, there are differences in anxiety before and after spiritual counseling for earthquake victims in Lombok, so it can be concluded that there is an influence of spiritual counseling on anxiety levels in Lombok earthquake victims. 
Table 3. Level of Anxiety Before and After Intervention N = 25

\begin{tabular}{lcc}
\hline \multicolumn{1}{c}{ Level of Anxiety } & $\begin{array}{c}\text { Frequency } \\
\text { (f) }\end{array}$ & $\begin{array}{c}\text { Percentage } \\
(\%)\end{array}$ \\
\hline $\begin{array}{l}\text { Level of Anxiety before Intervention } \\
\text { Moderate }\end{array}$ & 25 & 100,0 \\
& & \\
Level of Anxiety After Intervention & 22 & 88,0 \\
Mild & 3 & 12,0 \\
Moderate & & \\
\hline
\end{tabular}

Table 3 shows that anxiety felt by respondents before spiritual counseling was done all experienced moderate levels of anxiety $100 \%$,and anxiety felt by respondents after spiritual counseling was undergoing with mild anxiety as many as 22 people $88 \%$ and moderate anxiety 3 people $12 \%$.

\section{DISCUSSION}

The earthquake in Lombok on July 29th, 2018 with a magnitude of $6.4 \mathrm{MW}$ caused damage to infrastructure and caused fatalities in North and East Lombok. The next earthquake occurred on August $5^{\text {th }}, 2018$ with a strength of $7 \mathrm{MW}$, which caused severe damage and casualties in almost all areas of Lombok, especially West Lombok and North Lombok. Subsequently after shocks occurred on August $9^{\text {th }}, 2018$ with a strength of $6.2 \mathrm{MW}$ (Meteorology Climatology and Geophysics Council, 2018). West Lombok Regency is one of the earthquake-affected districts which is quite severe, one of them is in Gunungsari Village and Gerimak Indah Village. Hundreds of residents' houses were destroyed and many residents suffered minor injuries, serious injuries and fractures. In addition to physical impacts, earthquake events also have psychological effects such as anxiety. Anxiety is a response to certain situations that threaten and is a normal thing to happen (Kaplan, \& Sadock, 2007). Anxiety is an individual experience that is subjective in the form of feelings of fear, worry, difficulty and distress toward something that is realistic or unrealistic and it felt by individuals as something that is not pleasant (Sobur, 2013).

Univariate analysis results showed that all respondents undergo anxiety in the medium category with different scores. The instrument used in this research was the Hamilton Anxiety Rating Scale (HARS) questionnaire, which divided anxiety into 5 levels of anxiety, which are not anxious, mild anxiety, moderate anxiety, severe anxiety and panic. Anxiety symptoms felt by respondents based on the HARS questionnaire include fear, having a bad feeling, feeling tense and agitated, fearing darkness, fear of being alone, fearing crowds and being easily shocked, insomnia, insomnia, decreased concentration and interest, and symptoms somatic such as headaches, muscle aches, tense muscles, difficulty swallowing, trembling, frequent urination, palpitations and feeling tightness.

This result is in line with the survey which showed that $85.2 \%$ of earthquake victims experienced neurosis symptoms, $29.5 \%$ victims experienced psychotic symptoms, and $64.7 \%$ victims experienced PTSD symptoms. The results of a qualitative study of earthquake victims' complaints showed that almost all victims expressed fear, anxiety to enter their homes due to the earthquake, experienced family and economic problems (Dwidiyanti M., et al., 2018). The results of counseling in session I, respondents revealed that they still feel scared in the dark and alone. When the lights go out, especially if the lights go out at night, respondents immediately leave the house and be alert because they feel traumatized by the earthquake. One of the respondents with the highest anxiety score revealed that the respondent was still accompanied to the bathroom if the lights went out. Other respondents said that they had started closing doors and gates, but did not dare to be locked, some also stated that when they went to the bathroom to take a shower, defecate or urinate, 
Spiritual counseling on anxiety level in (Lombok) Indonesian earthquake victims

they did not dare to lock the bathroom door from the inside.

Preliminary screening results show that earthquake victims still experience mild and moderate anxiety. The anxiety experienced by respondents in the moderate category, no respondents experienced anxiety on severe and a panic categories. Crisis and Recovery Center (CRC) Team of Faculty Psychology's Gadjah Mada University found that $2.5 \%$ of the population experiencing mental burdens in the aftermath of the earthquake will find it difficult to adjust to the medium and long term. This means that survivors will need psychological help starting from the $3^{\text {rd }}$ week to the next 3 months. Furthermore, $1 \%$ of the population will undergo psychological problems in a longer period, namely the victims whose houses were severely damaged (Dewita, 2012). These findings are in line with the results of this research, which did not find respondents in the category of severe anxiety or panic.

Anxiety in the moderate category that is still experienced by respondents can be influenced by gender, age, level of education and experience during an earthquake (Stuart, \& Laraia, 2005; Videbeck, 2008). Respondents in this research were almost entirely women, who felt more anxious about their disabilities compared to men. Men are more active, exploratory, whereas women are more sensitive. Other studies have shown that men are more relaxed than women. In line with previous studies showing that women have a higher risk for anxiety due to trauma. Other research also found that women think more about disasters and have a deep emotional attachment to the family than men. Most of the respondents in this study are not in school or have low education, this is a risk factor for stress, mental health disorders due to lack of knowledge about post-disaster management and trauma healing (Dwidiyanti, et al., 2018)

In addition, the anxiety experienced may be caused by bad experiences during an earthquake, such as a destroyed house or injury. Previous research stated that the prevalence of psychological problems would be higher in vulnerable groups, namely victims who suffered injuries or broken bones, pregnant women and the elderly (Adami, 2013). The results of this research found that one of the respondents was a mother who was 9 months pregnant at the time of the earthquake and gave birth in an ambulance due to damage to public health center facilities. Respondents in this research are also mostly elderly, where the elderly are one of the vulnerable groups. This caused respondents to still feel anxious, even though the earthquake had already passed 8 months.

Based on the bivariate results it can be seen that the anxiety felt by respondents before and after spiritual counseling, has a value difference of 9.56 with a standard deviation of 4.23 . The $p$-value $=0,000$ indicates that this value is smaller than the alpha value of $5 \%(0.05)$, meaning that there are differences in anxiety before and after spiritual counseling in Lombok earthquake victims, so it can be concluded that there is an influence of spiritual counseling in reducing anxiety levels. The results of previous research concluded that there was an influence of spiritual support on reducing anxiety levels in preoperative patients in the Operating Room of Dr. Soepraoen Hospital Malang (Wulandari, 2013).

The results of this research found the average anxiety score in the Gerimak Indah Village was higher than the average anxiety score in Gunungsari Village. The results of counseling in session 2 found that respondents in Gunungsari village routinely attend weekly recitation, either at the mosque in the village where they live or at the mosque in the neighboring village. Anxiety can be influenced by external factors, including: environmental conditions; environmental conditions around the earthquake affected community can cause a person to become stronger or vice versa in dealing with problems, for example an environment that has routine religious study activities, wherein the research emphasizes the importance of praying and submitting to Allah SWT. This is likely to affect individual anxiety levels, so different anxiety scores are obtained in Gunungsari Village and in Gerimak Indah.

Excessive anxiety has a detrimental impact on the mind and body, even cause of physical illnesses (Williams, et al., 2004). The research showed that about $75 \%$ of 373 study subjects with a history of anxiety had undergo major depression and would experience anxiety in a lifetime. Anxiety is also considered as one of the inhibiting factors in 
Spiritual counseling on anxiety level in (Lombok) Indonesian earthquake victims

the learning process that can interfere with the performance of cognitive functions of someone who will have difficulty in concentrating, remembering and difficulty in solving problems. Furthermore, anxiety can interfere with attention, memory, alertness and the process of recalling information that has been stored that tends to interfere with the learning process (Kusrini, 2015). Therefore, anxiety needs to get treatment from health workers, one of them is nursing staff.

Nursing interventions that can be given to clients who experience anxiety based on Nursing Intervention Classification include counseling (Bulechek, 2013). Counseling is a process that focuses on the needs, problems or feelings of clients through active two-way communication, exchange of experiences, providing solutions based on mutual agreement to find ideas to improve or support coping, problem solving and creating good interpersonal relationships. One type of counseling that can be applied to earthquake victims is spiritual counseling. Previous research explained that there was a significant effect of nurses' spiritual counseling on the level of anxiety in the families of patients treated in the ICU at the Sleman District Hospital (Sugiyanto, 2014).

Through spiritual counseling in session 2 respondents were given the opportunity to express spiritual solutions that have been done to overcome the anxiety that exists. The results of counseling show when someone is struck down by a disaster, usually they will get closer to God by increasing worship and other good deeds. This was revealed by most respondents who claimed to put their trust in submitting everything to God. They are grateful to be given safety. That experience brought them closer to God. Ideally, they should interpret disaster as a disaster, not a disaster or doom. Earthquake is interpreted as God's strong warning to humans who have been wallowing in sin and lies for a long time. Therefore, as a disaster, disaster is not the end of everything. Disasters can be transformed into something that has meaning, not vanity let alone cursing. Next, respondents were given an understanding of the importance of the spiritual aspects in dealing with disasters. Respondents directed to always live in the nuances of faith in God and interpret their activities in this life as worship to God. That feeling will make it strong in dealing with all life's problems, including the earthquake that is experienced.

Third Session ofthe research process was to examine the level of anxiety experienced by respondents after spiritual counseling and it was found that almost all respondents had decreased anxiety levels or were in the mild category. Spirituality is useful in efforts to solve various problems in life. Spirituality can prioritize of goals. Moreover, the spiritual person is more adaptable when handling traumatic events. They are also better able to find meaning in a traumatic crisis and get guidance to decide what exactly needs to be done (Adami, 2013). Therefore, with spiritual counseling intervention, it can affect the anxiety level of victims of the Lombok earthquake, where respondents initially experience anxiety in the moderate category, then drop to anxiety in the mild category.

Spiritual counseling is counseling that directs the counselee to God with the basic assumption that humans are creatures created by God. Humans experience a break with God due to sin. The healing process is achieved through a counseling strategy which is the basic plan of intervention to achieve the goal of counseling, namely the healing of inner wounds (Witoha, 2003). The first goal is to help survivors to experience their full and complete experience. Complete experience is a solid foundation for further change, healing and holistic (physical, mental, social and spiritual) growth (Imanudin, 2010). Based on the results of previous studies, it can be concluded that the emotional freedom technique, spiritual intervention is proven to reduce post-traumatic stress disorder in adolescent victims of the eruption of Mount Merapi, which is indicated by a decrease in post-traumatic stress disorder scores. All participants felt calmer, relaxed, and comfortable after intervening in a spiritual emotional freedom technique with three simple techniques namely set-up, tune-in and tapping so that feelings of fear, sadness, anxiety, trauma due to the eruption of Mount Merapi were reduced and all participants can conduct spiritual intervention emotional freedom technique independently after being guided by a spiritual emotional freedom technique therapist (SEFT) and assisted by SEFT coterapists . 
Spiritual counseling on anxiety level in (Lombok) Indonesian earthquake victims

Individuals who undergo post-traumatic stress disorder, have the complexity of the problem, so it is necessary to have a comprehensive and professional counseling approach (Darimis, 2012). In this research, this theistic spiritual counseling if used in dealing with post-traumatic stress disorder can help individuals to be stronger, able to survive, resilient, and able to alleviate the problem of posttraumatic disorders through daily understanding, belief and worship in their religion. This spiritual counseling model develops inseparably from the assumptions that God exists, humans are God's creatures, there is a supernatural spiritual relationship process between humans and God, and the counselee has confidence in God's power will have the power to overcome his problems and develop his potential (Yusuf, 2011).

\section{CONCLUSION}

The results showed that all respondents undergo the moderate anxiety with different scores. After the implementation of spiritual counseling, the results of statistical tests showed that there were significant differences between anxiety levels before and after spiritual counseling ( $p$-value 0,000 ). Then it can be concluded that there is an influence of spiritual counseling on the anxiety level of Lombok earthquake victims.

\section{RECOMMENDATION}

This research can be given to all respondents and their families and communities affected by the earthquake to improve the spiritual quality by attending religious studies routinely which can indirectly calm the mind and reduce anxiety or trauma caused by the earthquake.

\section{REFERENCES}

Adami, A. (2013). Psycho-Spiritual Therapy: Anticipating Post-Earthquake Stress. Retrieved from http://pikirdong.org/terapi-psiko-spiritualmengantisipasi-stres-pasca-gempa/commentpage-1/
Ando, S, Kuwabara, H, Araki, T, Kanehara, A, Tanaka, S, Morishima, R; Kondo, S \& Kasai, K. (2018). Mental Health Problems in a Community After the Great East Japan Earthquake in 2011:a Systematic Review.HarvRevPsychiatry,25(1):1528.https://dx.doi.org/10.1097/HRP.0000000000 000124

Bulechek, G.M.(2013). Nursing Intrventions Classification (NIC). Mosby: Elsevier.

Darimis. (2012). Eradication of Post Traumatic Stress Problems Based on Theistic Spiritual Counseling Model (A Theoretical and Practical Review of the Traumatic Symptom). Prosiding International Seminar \& Workshop Post Traumatic Counseling). Retrieved from http://repository.radenintan.ac.id/1502/1/(2012) _proceeding_Pencegahan_Alienasi.pdf.

Dewita, S. (2012). Psychological Conditions of Post-Disaster Communities. Retrieved from https://sisridewitayaipsi07.blogspot.com/2012/0 4/kondisi-psikologis-masyarakat-pasca.html.

Dwidiyanti, M., Hadi, I., Wiguna, R., \& Ningsih, H. (2018). Description of the Risk of Mental Disorders in Victims of Earthquake Natural Disasters in the West Nusa Tenggara Lombok. Holistic Nursing and Health Science, 1(2), 82-91. Retrieved from https://ejournal2.undip.ac.id/index.php/hnh s/article/view/3419

Imanudin, D.E. (2010). Disaster Counseling: Study of Concepts and Post-Traumatic Stress Disorders (PTSD) Therapy. JurnalllmuDakwah, 4(15): 957-988. https://www.neliti.com/publications/63859/kons eling-paska-bencana-telaah-atas-konsep-danterapi-post-traumatic-stress-disorder.

Kaplan, H \& Sadock,B. (2007). Consite textbook of Child and Adolescence Psychiatry. Maryland: William \&Wilkins. 
Kusrini, S.E. (2015). Effects of Health Education on Adolescent Girls' Anxiety Facing Puberty. Tesis. Yogyakarta: Univesitas Gadjah Mada. Retrieved http://etd.repository.ugm.ac.id/index.php?act=vi ew\&buku_id=91763\&mod=penelitian_detail\&su $\mathrm{b}=$ PenelitianDetail\&typ=html.

Lieber, M. (2017). Assesing The Mental Health Impac to the 2011 Great Japan Earthquake, Tsunami and Radiation Disaster on Elementary And Middle School Children in the Fukushima Prefectura of Japan. PLOS ONE, 12(1):1-14. https://doi.org/10.1371/journal.pone.0170402

Lubis, A.S. (2007). Islamic Kyai Counseling and Islamic Boarding School. Yogyakarta:elSAQ Press.

Meteorology Climatology and Geophysics Council. (2018). Lombok Earthquake. Retrieved fromhttps://www.bmkg.go.id/berita/?p=pulaulombok-kembali-diguncang-gempabumi-m7-0tidak-berpotensitsunami\&lang=ID\&tag=lombok.

Purqoti, D.N.S. (2017). The Effect of Spiritual Counseling on the Psychological Adaptation Ability of Stroke Patients in NTB Provincial Hospital. Tesis.Universitas Muhammadiyah Jakarta.

Ramirez, M. (2005). Epidemiology of Traumatic Injuries from Earthquakes. Retrieved from https://doi.org/10.1093/epirev/mxi005

Sherchan, S, Samuel, R, Marahatta, K, Anwar, N, Van, Ommeren MH \& Ofrin R. (2017). PostDisaster Mental Health and Psychosocial Support: Experience from the 2015 Nepal Earthquake. WHO South-East Asia Journal of Public Health, 6(1),22-29. https://dx.doi.org/10.4103/2224-3151.206160

Sobur, A. (2013). General Psychology in Historical Paths. Bandung: CV Pustaka Setia.
Stuart, G.W \& Laraia, M.T. (2005). Principle and Practice of Psychiatric Nursing. 8thedition. The Mosby Company: Elsevier.

Sugiyanto, B. (2014). PThe Influence of Nurse Spiritual Counseling on the Level of Anxiety in the Family of Patients Treated in ICU Room Sleman Yogyakarta Hospital. Publication manuscript.Program Studi IImu Keperawatan Sekolah Tinggi IImu Kesehatan 'Aisyiyah Yogyakarta. Retrieved from http://digilib.unisayogya.ac.id/273/1/Naskah\%2 OPublikasi\%202.pdf.

Videbeck, S.L. (2008). Textbook of Psychiatric Nursing. Jakarta: EGC.

Williams, L.A, Goodwin, R.D, \& Cox, B.J. (2004). Depression and Anxiety Associated with Three Pain Conditions: Results from a Nationally Representative Sample.Pain, 111(1):77-83. http://dx.doi.org/10.1016/j.pain.2004.06.002

Witoha. (2003). Spiritual Counseling Technical and Strategies. Retrieved from https://lib.atmaja ya.ac.id/default.aspx?tabID=61\&src=k \&id $=1549$.

World Health Organization. (2013). Building back better. Sustainable mental health care after emergencies. Retrieved from http://apps.who.int/iris/beatstream/10665/85377 /1/978241564571_eng.pdf?ua=1.

Wulandari, F. (2013). Effects of Spiritual Support on Decreasing Anxiety Levels in Preoperative Patients in the Operating Room of Dr. Soepraoen Hospital Malang. Retrieved fromhttp://eprints.umm.ac.id/28477/.

Yusuf, S. (2011). Theistic Counseling: A Hypothetical Approach.Bandung: UPI Press 